\title{
TRACING A VANISHING HERITAGE: THE HUNGARIAN RUSTBELT
}

\author{
A FACTORY TOWN THAT BELONGS TO THE PAST... \\ SOCIAL CHANGES IN ÓZD AND ITS SURROUNDINGS FROM \\ THE SYSTEM CHANGE UNTIL TODAY, BY PÉTER ALABÁN \\ (KRONOSZ PUBLISHING HOUSE, 2020) ${ }^{1}$
}

ESZTER BARTHA ${ }^{2}$

Hungarian sociography has been a specific genre, a mixture of sociology and belles-lettres. It was very popular in the interwar era, when Hungarian writers and social scientists described a wide range of social problems (the misery of the landless peasantry, the surviving feudal relations in the countryside, the poverty of the villages, etc.), and was also targeted at the regime as a sharp form of social critique.

While Hungarian sociography flourished in the interwar era - after the tragic experience of World War I, the subsequent revolution, and the establishment of the Hungarian People's Republic followed by the White Terror and the restoration of a right-wing, autocratic regime, which preserved many feudal privileges -, the same cannot be said about the times which followed the system change of 1989 that witnessed a general downgrading of social sciences - or at least their diminishing popularity in the public sphere and social media.

Originally founded in 1937, the series entitled The Discovery of Hungary (Magyarország felfedezése) was re-founded in 1970 and attracted several excellent authors, while it continued to preserve its critical stance. It succeeded in surviving the lean years, but its impact, nevertheless, has not extended beyond a narrow intellectual circle in spite of the fact that it addresses much

1 The Hungarian title of the book is "Egykor volt gyárváros...Társadalmi változások Ózdon és környékén a rendszerváltástól napjainkig."

2 Eszter Bartha is associate professor at the Faculty of Humanities, Eötvös Loránd University, Budapest, Hungary, email: barthaeszter@hotmail.com 
wider socioeconomic and political issues. This is all the more regretful since we are in great need of discovering more of provincial Hungary at a time when we can witness the coexistence of many "Hungarys," while the "centre" - with few exceptions - possesses hardly any relevant knowledge of peripheral areas that have been left behind. These few exceptions include the above-mentioned series, the book of János Ladányi entitled Leselejtezettek (The Hungarian Precariat), the rural research of Imre Kovách, the working-class studies of Tibor Valuch and the extensive oral history project of Gábor Scheiring in the Hungarian rustbelt. We should also mention here the academic organizational work of Péter Pál Tóth, who has made considerable effort to promote the survival of the series Magyarország felfedezése. The committed anti-capitalist, left-wing journal entitled Eszmélet (Consciousness) also offers a forum for system-critical authors and papers, among them an article by Péter Alabán, in which he gives a summary of his main findings from Ózd.

The town of Ózd exemplifies the major characteristics of a socialist industrial centre, where the leading branches (heavy industry, metallurgy, mining, the chemical industry, etc.) were closed down or suffered very heavy losses after the system change. To be sure, Ózd had a rich pre-socialist past: it was also an important centre of Hungarian mining and metallurgy in the interwar era, with a distinctive mining culture and work ethic. After World War II, when the Communist parties throughout Eastern Europe followed the Stalinist path of forced industrialization, Ózd and the region of Northern Hungary, where the factory town is located, became the main beneficiary of socialist investment. In 1981, the town counted more than 46,000 inhabitants, and its neighborhood boasted flourishing mining villages, as mining was one of the best-paid manual jobs.

The system change stripped Ózd of its formerly privileged industries. Given its distance from Western countries and poor transport infrastructure, the town failed to attract rich investors from the West. Hungary's industrial centre moved from Northern Hungary to the Western parts of the country, and many professionals followed this trajectory. In 2011 only about 35,000 people were living in the town, many retired or unemployed, who could not afford to move out. Many of the once flourishing mining villages have become social ghettoes for impoverished Roma people who could not find other employment after the closing of the mines and the factory.

Although A factory town... is the first monograph of Péter Alabán on the subject, he is very familiar with the past 30 years of the town as he was able to observe the social changes first as a teenager and later as a teacher and the headmaster of a vocational and secondary school. The book can be seen as the result of more than ten years of fieldwork and ethnographical observation, 
including the mapping of selected villages in the neighborhood. While in Germany there has been intensive research of newly formed "rustbelts," Hungarian mono-industrial towns have received little critical attention for the aforementioned reasons. In this intellectual milieu, the book is a refreshingly different endeavor which offers a documentary-like precise description of the decline of the town that followed the disintegration of factories after the system change, the ills of privatization, and the negative social processes that accompanied the rearrangement of industrial centers in Hungary.

The precedents can be found in the documentary series of Tamás Almási about Ózd, which the author also analyzes in the book. The series is a moving account of the decline of the factory town from 1987 until the end of the 1990s. We can also follow this sad path towards social disintegration and its physical equivalent - the decay and disappearance of the industrial landscape - through the increasing disillusionment of the director with the system change and his growing bitterness: while in the first piece of the series (Szoritásban-Squeezed) we encounter rather unpleasant party functionaries who administer the fate of the factory and the workers, in one of the last pieces, entitled Meddö (Infertile), Roma people living in deep poverty collect iron scraps from an ash-heap...

One indisputable merit of Alabán's book is that it places and analyzes the processes of disintegration that have accompanied the collapse of socialist industry in a local context. The most important problem of Ózd and its surroundings are that the decline and subsequent closing down of metallurgy and mining operations occurred hand in hand with the decay of infrastructure. The situation was further worsened by the fact that, thanks to its unfavorable location (no railway or highway to the West), the town was unable to attract new investors, industrial branches, or significant multinational companies. The result: gradual social decline and disintegration, a lack of job opportunities, high unemployment, the escape of specialists and intellectuals from the town, while the remaining population lives on workfare and welfare and inevitably become even more impoverished and resourceless. There were also many who chose another way out: they escaped from this sad reality either through alcoholism or suicide. A foundryman in the first piece of the series about Ózd of Almási's was able to announce with pride that he would never leave the town, but when the director returned to Ózd in 1997 the same worker was no longer alive. His widow told the director with tears in her eyes that, before his suicide, he "often went to the shed in the garden, to cry" (Alabán 2020: 186).

As the books of Réka Várkonyi-Nickel (Rimaiak a gyárak völgyében The People of Rima in the Valleys of the Factories) and Péter Nagy (A Rima vonzásában - The Magnetic Field of Rima) introduce, the factory and the mine also had a social-integrating role before nationalization after World War II, and 
this tradition also continued under state socialism (Tibor Valuch: Mindennapi történeteink - Our Everyday Life Stories). The closing down of the factory and the mines accelerated the process of social disintegration and individual and local identity crises, and it triggered feelings of general and persistent insecurity in the town and the region.

In his book, Alabán also describes the crisis of the nearby villages that make up the hinterland of the factory in Ózd: the once flourishing, neat and tidy mining villages in the region of Barkóság today are a sad picture of impoverishment (we could even say misery) with collapsing houses, decaying or disappearing infrastructure, and the futureless situation of the inhabitants, where the only income is from workfare and welfare, which is true even if there are some rare exceptions (e.g. Kissikátor, which still continues to be a picture of an orderly village thanks to the efforts of the local population).

The crisis of socialist industry and the destruction of factories (also in the physical sense of the word) were accompanied by the disappearance of a formerly strong work ethic which had a century-long tradition. This in turn creates a further obstacle to the settlement of transnational companies. We now witness the growing up of a third and fourth generation (especially in Roma communities, since Roma people are already disadvantaged in the labor market), whose socialization lacks the experience of continuous, regular, contracted work, and whose members have only seen and experienced deep poverty, misery, and multiple deprivation in their surroundings.

There are only a few associations/NGOs or socially committed people - such as Péter Alabán himself, who also works as the headmaster of a school. He has been able to utilize this experience in his book, where he devotes a chapter to a discussion of the urgent problems of vocational schools, starting from the lack of resources through the lack of training opportunities to the problem of discrimination. Vocational schools mainly "attract" children who have no hope of getting a better place after elementary school. This is also reflected in the ethnic background of the students: non-Roma parents will do everything to send their children to good secondary schools, whereas Roma children mostly have to content themselves with places in vocational schools. Many of them drop out even from these schools, which leads to a vicious circle of unemployment, living on workfare or social benefits, deep poverty, alcoholism, game- or drug- addiction, criminality, and prostitution (see the unforgettable movie of Kusturica, the Time of the Gypsies).

While the government has invested a lot into (propagating) the solution to the crisis of vocational training, it is also true nationally that even larger transnational companies have problems recruiting a new, young workforce. Alabán offers a clear and detailed statistical analysis in order to prove that in Ózd 
we can observe the simultaneous existence of unemployment and a shortage of skilled labor - since children who drop out of the educational system (early school leaving) inevitably "re-live" the fate of their parents.

The book also takes account of another sad process: alongside the workers and the traditionally strong work ethic, we witness the gradual deterioration of the physical environment and the decay or outright destruction of a large part of the industrial heritage. We can find a detailed analysis of the state of the national conservation of industrial heritage by Györgyi Németh in a book entitled Munkás-kultúra-örökség (Working-class-culture-heritage), published in 2020; and the work of Alabán complements this wider picture with a local report. Alabán gives several international examples of the successful conservation of industrial heritage (in which the state assumed a decisive financial role), leading to the former sites now functioning as tourist attractions - the most successful example being the Ruhr region. In contrast, in Hungary there has been neither the capital nor the serious intent to save this heritage (this is true of all governments after the system change).

While we can, of course, understand those people (mainly youth) who escape from there (even if they have strong feelings of homesickness), in this situation we should all the more appreciate those who, like Péter Alabán, decide to stay in Ózd, and in the face of all odds do something for the region and its children. After all, a will to change one's life has not been missing from the inhabitants of town: it is not accidental that many of the local youth now work in the catering industry in London, while some of the professionals have even reached the ranks of the international middle class. Their full social integration is, however, missing - but this is the topic of another book.

Borsod is the region where Ózd is located. Sorsod-Borsod (Your fate is Borsod) - as the folk saying holds (this is also the title of a movie). What Péter Alabán could do for this region he has done, and he will continue to do in the future. It would be good if this region regained its visibility so that the "center" could maintain connections with and relevant knowledge of provincial Hungary, at least before the next parliamentary elections. Authors such as Chris Hann and Gábor Scheiring have called attention in the international academic arena to the problems of the Hungarian province. Péter Alabán's book complements this with an illuminating view "from inside," which is recommended not only to experts but also to a wider audience that is socially minded or socially sensitive - and indeed, to anybody who wants to know more of the country in which they live. 
